The Power of Representation 



\title{
The Power of Representation
}

Publics, Peasants, and Islam in Egypt

\author{
Michael Ezekiel Gasper
}

Ч

STANFORD UNIVERSITY PRESS

STANFORD, CALIFORNIA 


\section{Stanford University Press \\ Stanford, California \\ (C) 2009 by the Board of Trustees of the \\ Leland Stanford Junior University. \\ All rights reserved.}

No part of this book may be reproduced or transmitted in any form or by any means, electronic or mechanical, including photocopying and recording, or in any information storage or retrieval system without the prior written permission of Stanford University Press.

Printed in the United States of America on acid-free, archival-quality paper

Library of Congress Cataloging-in-Publication Data

Gasper, Michael, I963-

The power of representation : publics, peasants, and Islam in Egypt / Michael Ezekiel Gasper.

p. $\mathrm{cm}$.

Includes bibliographical references and index. ISBN 978-0-8047-5888-8 (cloth : alk. paper)

I. National characteristics, Egyptian. 2. Egypt-Intellectual life.

3. Peasantry-Egypt-History. 4. Islamic modernism-Egypt-History.

I. Title.

$$
\begin{aligned}
& \mathrm{DT}_{70} \cdot \mathrm{G}_{37} 2009 \\
& \text { 962'.04-dc22 } \\
& 2008 \text { OI I } 83 \text { I }
\end{aligned}
$$

Typeset by Westchester Book Group in Io/I 2 Sabon 
To my parents who have always unconditionally supported me in all of my sundry endeavors 
The phenomena of political modernity-the rule by modern institutions of the state, bureaucracy, and capitalist enterprise-is impossible to think of anywhere in the world without invoking certain categories and concepts, the genealogies of which go deep into the intellectual and even theological traditions of Europe. Concepts such as citizenship, the state, civil society, public sphere, human rights, equality before the law, the individual distinctions between public and private, the idea of the subject, democracy, popular sovereignty, social justice, scientific rationality, and so on all bear the burden of European thought and history. One simply cannot think of political modernity without these and other related concepts that found a climatic form in the course of the European Enlightenment and the nineteenth century.

-Dipesh Chakrabarty, Provincializing Europe 